\section{Елизабет Грос}

\section{ЛЕЗБЕЈСКИФЕТИШИЗАМ?}

$B^{\circ}$ о психоаналитичкиот дискурс, фетишизмот е единствено машка перверзија. ${ }^{1}$ Во психоаналитичката литература постои општа согласност (со многу малку исклучоци), дека фетишизмот е машка перверзија, и се претполага дека е невозможно негово постоење кај жените. Иако во една смисла не сакам да не се согласувам со ова тврдење - психоаналитички гледано, нема никаква смисла жените да бидат фетишисти, и незамисливо е жените да добијат задоволување од употребата на неживи предмети или само од некои непотполни предмети² - во една друга, постратешка и пополитичка смисла се чини оправдано да се сугерира, како што тоа го прави Наоми Шор во нејзината анализа на Жорж Санд (1985), дека може да постои една форма на женски фетишизам, и понатаму, да се тврди дека лезбејството е негов најочевиден и најопиплив израз.

Како и фетишиститот, јас исто така сакам да го имам и едното и другото: напоредно со психоаналитичката ортодоксија, јас ќe се согласам дека женскиот фетишизам е физички незамислив, иако исто така сакам да тврдам дека и "нормалната" (т.е., хетеросексуална) женственост и женската хомосексуалност можат да бидат согледани во социополитичка смисла, и покрај бројните нивни психоаналитички описи, како модуси на фетишизам (на ист начин, тврдам, како што феминизмот може да биде согледан во форма на масовна или колективна психоза, како

\author{
Elizabeth Grosz
}

\section{LESBIANFETISHISM?}

n psychoanalytic discourse, fetishism is a uniquely male perversion. ${ }^{1}$ In the psychoanalytic literature it has been generally agreed, (with very few exceptions), that fetishism is a male perversion, and its existence in women is assumed to be impossible. While in one sense I do not want to disagree with this claim-in psychoanalytic terms, it makes no sense for women to be fetishists, and it is unimaginable that women would get gratification from the use of inanimate objects or mere partial objects alone ${ }^{2}$-in another, more strategic and political sense, it seems plausible to suggest, as Naomi Schor does in her analysis of George Sand (1985) that there can be a form of female fetishism, and to claim, further, that lesbianism provides its most manifest and tangible expression.

Like the fetishist, I too want to have it both ways: along with psychoanalytic orthodoxy, I will agree that female fetishism is psychically inconceivable, while I also want to claim that both "normal" (i.e., heterosexual) femininity and female homosexuality can be seen in socio-political terms in excess of their psychoanalytic descriptions, as modes of fetishism (in the same way that 1 would claim, feminism can be seen as a form of mass or collective psychosis, a political disavowal of women's social reality as oppressed). I will not deal specifically with any quasi-fetishistic variations of lesbianism (sadomasochism, trans- 
политичко порекнување на социјалната реалност на жените како угнетувани). Посебно нема да се занимавам со никакви квази-фетишистички варијации на лезбејството (садо-мазохизмот, трансвестизмот, употребата на сексуални параферналии, исполнувачи, или протези). Без оглед на нивната фасцинантност, тие не може да се сметаат како фетиши се додека најнапред не се покаже дека женскиот фетишизам е возможен.

Во првиот дел од овој есеј ќе ги испитувам ортодоксните психоаналитички теоретичари, скицирајќи ги Фројдовите и Лакановите сфаќања; во вториот дел ќе си поигрувам со овие ортодоксни гледишта, растегнувајќи ги вон границите на нивната толеранција. Полусериозно, полуигриво, ова нема да биде само читање на психоаналитичките концепти и методи, туку исто така и испитување на начините на кои феминистичката теорија може да ги исползува токму оние дискурси кои сака - и треба - да ги подрие за да ги исполни сопствените цели и заложби, ползувајќи ги нив како стратегиски орудија во нејзините сопствени борби. Стремежов е ем суштествен ем методолошки, е и анализа на полезноста на психоаналитичките концепти и илустрација на тоа како феминист(к)ите можат да ги читаат патријархалните текстови кои не им се по волја, така што истите да можат да бидат активно разработени и стратегиски впрегнати за исполнување на заложби за кои не биле наменети. Истовремено, есејов може да се смета како крајно спекулативно и крајно прелиминарно истражување на можноста за "лезбејска теорија“, теорија на и за лезбејките. Дали психоанализата ќе се докаже или не како полезна за такви проекти останува една од моите овдешни клучни, иако недоразвиени, преокупации.

\section{Психоанализата и фетишизмот}

Фројд го покрена прашањето за фетишизмот рано во неговата кариера (во првото издание на Трите есеи за теоријата на сексуалноста (1905)) и повторно му се врати во еден од последните написи во неговиот живот, „Расцепување на егото во процесот на одбрана" (1938). Тој се vestism, the use of sexual paraphernalia, implements, or prosthesis). Fascinating as these may be, they cannot be regarded as fetishes until it can first be shown that female fetishism is possible.

In the first part of this essay I will examine orthodox psychoanalytic theorists, outlining Freud's and Lacan's notions; in the second part, I will play with these orthodox views, stretching them beyond the limits of their tolerance. Half-serious, halfplayful, this will be not only a reading of psychoanalytic concepts and methods, but also an examination of the ways in which feminist theory may utilize precisely those discourses it wishesand needs-to subvert in order to ensure its own goals and purposes, using them as strategic tools in its own struggles. This effort is both substantive and methodological, an analysis of the usefulness of psychoanalytic concepts and an illustration of how feminists may read patriarchal texts against the grain, so that they may be actively worked upon and strategically harnessed for purposes for which they were not intended. At the same time, it may be regarded as a highly speculative and preliminary investigation of the possibility of "lesbian theory," theory of and for lesbians. Whether psychoanalysis will prove useful or not for such projects remains one of my key, if underdeveloped, concerns here.

\section{Psychoanalysis and fetishism}

Freud raised the question of fetishism early in his career (in the first edition of The Three Essays on the Theory of Sexuality (1905a) and returned to it again in one of the last papers of his life, "Splitting of the Ego in the Process of Defence" (1938). He turned to the topic every few years, in Jensen's 
навраќаше на темата секои неколку години во Јенсеновата Градива (1907), неговата студија на случајот со Човекот стаорец (1909), неговата студија за Леонардо (1910), и во написот "Негација" (1925), особено сосредоточувајќи се на темата во написот „Фетишизам“ (1927).

Во првиот од трите есеи, Фројд разграничува два типа на сексуална аберација, оној во кој постои девијација во сексуалниот објект (овде ги споменува хомосексуалноста, педофилијата и бестијалноста) и оној во кој постои девијација во сексуалната цел (трансвестизмот, воајеризмот, егзибиционизмот). Тој го вклучува фетишизмот во втората категорија иако тврди дека истиот може подеднакво да биде вклучен во првата, бидејќ негова главна карактеристика е сексуалното преценување на дел од телото или на некој нежив предмет. Преценувањето, карактеристика на анаклитичките или маскулините форми на сакање, го создава фетишот како таков, со тоа што доаѓањето до фетишистичкиот предмет е по себе доволно за доаѓaње до оргазмичко задоволување.

Фројд ги сметаше перверзиите како спротивни на неурозите: тие се позитивната и негативната страна од истата паричка. Перверзиите го избегнуваат потиснувањето што ги карактеризира неурозите. Первертот го изразува токму она што неуротикот го потиснува: первертот го прави она што неуротскиот субјект би сакал да го направи но не е во состојба бидејќи изразувањето на перверзниот нагон донесува повеќе незадоволство отколку задоволство. ${ }^{3}$ Во онаа мерка во која сексуалната „нормалност" има некакво значење за Фројд, таа е дефинирана во социјален поглед како копулативна не-инцестуозна хетеросексуалност. ${ }^{4}$ Лезбејството, како и машката сексуалност, е класификувано како перверзија. (Сосема е јасно дека за Фројд поимот на нормалност е попрво употребен дескриптивно одошто нормативно, и дека тој сериозно го дестабилизира терминот секојпат кога ќе се повика на него.)

Има неколку состојки кои се нужни за да се разбере Фројдовото поврзување на фетишизмот со развојните патеки отворени за маскулиниот субјект. Фетишистот, се
Gradiva (1907), his case-study of the Rat man (1909), his study of Leonardo (1910), and in the paper "Negation" (1925b), particularly focussing on it in the paper "Fetishism" (1927).

In the first of The Three Essays, Freud distinguished two types of sexual aberration, those in which there is a deviation in the sexual object (here he mentions homosexuality, pedophilia, and bestiality), and those in which there is a deviation in the sexual aim (transvestism, voyeurism, exhibitionism). He included fetishism in the second category, although he claimed that it could equally well be included in the first, because its main characteristic is a sexual overvaluation of a part of the body or an inanimate object. Overvaluation, a characteristic of anaclitic or masculine forms of loving, creates the fetish as such, the fetishistic object's attainment being sufficient in itself to bring about orgasmic gratification.

Freud regarded the perversions as the opposite of neuroses: they are positive and negative sides of the same coin. The perversions avoid the repression that characterizes the neuroses. The pervert expresses precisely what it is that the neurotic represses: the pervert does what the neurotic subject would like to do but is unable to because the expression of a perverse impulse yields more unpleasure than pleasure. ${ }^{3}$ Insofar as sexual "normality" has any meaning for Freud, it is defined in social terms as copulative, non-incestuous heterosexuality. ${ }^{4}$ Lesbianism, like male homosexuality, is classified as a perversion. (It is quite clear that for Freud the notion of normality is used descriptively rather than normatively, and that he seriously destabilized the term wherever he invoked it.)

There are several ingredients necessary to understand Freud's linkage of fetishism to the paths of development open to the masculine subject. The fetishist, it seems, undergoes the 
чини, поминува низ Ојдиповиот комплекс со еден главен елемент кој ја разграничува неговата положба од онаа на евентуалниот хомосексуалец или хетеросексуалец. Во последниве случаи, момчето е сведок на призор од женски гениталии и е под закана од кастрација во два временски одделени мига - редот е неважен. Фројд тврди дека има временски период во кој момчето е кадарно да го порекне едниот или другиот, во зависност од тоа кој прв се јавил. Малиот Ханс (Freud, 1910a), ни дава прекрасна илустрација: со раѓањето на неговата сестра Хана, тој го порекнува она што го гледа кога бебешката пелена е тргната настрана. Тој ѝ извикува на неговата мајка „но таа нема заби"(!) преместување, сугерира Фројд, од неговата перцепција на нејзината кастрираност. Тој не може веднаш себеси да си признае дека таа нема пенис (тоа би ја загрозило сигурноста на неговото поседување на органот), па така тој ја преместува својата перцепција на она што недостасува од гениталиите кон забите. Згора на тоа, подоцна момчето е под директна закана за кастрација од неговата мајка заради неговите мастурбирачки активности. Таа му се заканува дека ќе викне доктор, кој ќе му го отстрани неговото „мрдало". Уште еднаш, тој ја порекнува заканата и дрско извикува: „Па што? Јас ќе мрдам со мојот задник“. Ваквиот вид порекнување е „нормален“ психички одбранбен механизам кој им стои на располагање на децата од обата пола, и тој функционира првенствено во поглед на заканата од кастрирање (за момчињата) или нејзината симболичка актуалност (за девојчињата). Но во случајот на фетишизмот, различно е доколку обата фактора [т.е., призорот на женски гениталии и заканата од кастрирање] се јават едновремено. Во тој случај заканата го оживува споменот на перцепцијата што дотогаш била сметана за безопасна и во тој спомен наоѓa ужаснувачко потврдување. (Freud, 1940:276, курзивот додаден)

Овде Фројд тврди дека доколку момчето го доживува своето набљудување на кастрираната состојба на жената во исто време кога ја доживува заканата од кастрирање, тоа веке не може да се потпре на својата способност за порекнување на оваа перцепција; ниту, од друга страна, тоа може да ги прифати импликациите од заканата
Oedipus complex with one major element that differentiates his position from that of the eventual homosexual or heterosexual. In the latter cases, the boy witnesses the sight of the female genitals and is threatened with castration at two moments separated in time-the order is unimportant. Freud claims that there is a period of time in which the boy is able to disavow one or the other, depending on which occurs first. Little Hans (Freud, 1910a) provides the perfect illustration: with the birth of his sister Hanna, he disavows what he sees when the baby girl's diaper is removed. He exclaims to his mother "but she's got no teeth"(!)- - a displacement, Freud suggests, from his perception other castration. He cannot readily admit to himself that she has no penis (this would imperil the security of his own possession of the organ), so he displaces his perception of what is missing from the genitals to the teeth. At a later time moreover, the boy is directly threatened with castration by his mother for his masturbatory activities. She threatens to call the doctor, who will remove his "widdler." Once again, he disavows the threat and brazenly proclaims: "So what? I'll wid-die with my bottom." This kind of disavowal is a "normal" psychical defence mechanism available to children of both sexes, and it operates primarily with respect to the threat of castration (for boys) or its symbolic actuality (for girls). But in the case of fetishism, it is different if both factors [i.e., the sight of female genitals and the threat of castration] occur simultaneously. In that case the threat revives the memory of the perception which had hitherto been regarded as harmless and finds in that memory a dreaded affirmation. (Freud, 1940: 276. emphasis added)

Here Freud claims that if the boy experiences his observation of the female's castrated condition at the same time as he experiences the threat of castration, he can no longer rely on his ability to disavow his perception; nor, on the other hand, can he accept the implications of the castration threat, which mean the abandonment of his pleasure- 
за кастрирање, кои подразбираат напуштање на неговите сексуални нагони кои копнеат по задоволство и негово потчинување на Ојдиповската забрана:

Тој одговара на конфликтот со две спротивни реакции, од кои обете се оправдани и делотворни. Од една страна, со помош на извесни механизми тој ја отфрла реалноста и одбива да прифати било каква забрана; од друга страна, во ист здив тој ја признава опасноста од реалноста, го презема стравот од таа опасност како патолошки симптом и како резултат на тоа се обидува да го симне од себеси стравот...

На инстинктот му е допуштено да го задржи своето задоволување а кон реалноста е покажана соодветна почит. Но, се треба да се плати на еден или на друг начин, а овој успех е постигнат по цена на напукнување во егото кое никогаш не зацелува туку со време се зголемува. Двете спротивни реакции на конфликтот опстојуваат како средишна точка на расцепувањето на егото (1940: 275276).

Она што е клучно во овој момент е Ојдиповската конфигурација на фетишистичката етиологија. Фетишистот е момче/дете кое, од извесен разлог, без оглед дали овие два настана се јавуваат истовремено или не, не е во состојба да го разреши Ојдиповскиот конфликт во неговите различни алтернативи. Тоа не е кадарно или не сака да ја одобри пропишаната хетеросексуална патека напуштајќ ја мајката како љубовен објект и прифаќајќи ги пост-Ојдиповските ограничувања на неговите сексуални нагони преку идентификување со авторитетот на (симболичкиот) татко; ниту пак може, како хомосексуален син, да го прифати симболичкото кастрирање со цел да ја заземе "феминината" позиција и да усвои пасивна сексуална улога во односот кон неговиот татко. За разлика како од хетеросексуалецот, така и од хомосексуалецот, фетишистот не сака ништо да загуби: тој не е подготвен да "плати" за неговата желба соочувајќи се со Ојдиповската забрана, која го става момчето пред одвратниот избор - да се откаже од мајката или да го загуби пенисот - избор помеѓу неговиот најскапоцен објект и неговиот најскапоцен орган. seeking sexual impulses and his submission to the Oedipal interdict:

He replies to the conflict with two contrary reactions, both of which are valid and effective. On the one hand, with the help of certain mechanisms he rejects reality and refuses to accept any prohibition; on the other hand, in the same breath he recognized the danger of reality, takes over the fear of that danger as a pathological symptom and tries subsequently to divest himself of the fear...

The instinct is allowed to retain its satisfaction and proper respect is shown to reality. But everything has to be paid for in one way or another, and this success is achieved at the price of a rift in the ego which never heals but which increases as time goes on. The two contrary reactions to the conflict persist as the centre-point of a splitting of the ego (1940: 275-76).

For the moment, what is crucial is the Oedipal configuration of the fetishist's etiology. The fetishist is the boy/child who, for some reason, whether these two events occur simultaneously or not, is unable to resolve the Oedipal conflict in its various alternatives. $\mathrm{He}$ is unable or unwilling to take up the prescribed heterosexual path by abandoning the mother as loveobject and accepting the post-Oedipal restraints on his sexual impulses through identification with the authority of the (symbolic) father; nor can he, like the homosexual son, accept symbolic castration in order to take on the "feminine" position and adopt a passive sexual role in relation to his father. Unlike either the heterosexual or the homosexual, the fetishist wants to have his cake and eat it too: he is not prepared to "pay" for his desire by facing the Oedipal prohibition, which gives the boy the ghastly choice-give up the mother or lose the penis- a choice between his most precious object and his most precious organ. 
[Фетишот] останува белег за триумфот во поглед на заканата за кастрирање и заштита против неа. Тој исто така го спасува фетишистот да не стане хомосексуалец, обдарувајки ги жените со карактеристики кои што ги прават подносливи како сексуални објекти... Она што другите мажи треба да го придобиваат, напрегајќи се притоа, фетишистот може да го поседува без никаква мака. (Freud, 1927: 154)

Иронично, значи, фетишистот е анализанд за кој речиси нема изгледи дека ќе стапи во психоаналитички договор. Тој останува совршено среќен при својот љубовен објект (објект за кој нема изгледи дека ке им се спротистави на неговите желби и фантазии). И ако тој воопшто пристапи кон анализа, по сѐ изгледа, тоа ќe биде по барање на некој друг. Фетишот е супститут за, талисман на, фалусот, но не само на кој и да е стар фалус. За пред-Ојдиповското момче, највреден не е неговиот сопствен фалус (затоа што неговиот пред-Ојдиповски, имагинарен пенис сеуште не е издигнат до функција на фалус), туку на неговата мајка фалусот што неа ја обдарува со моќ и авторитет. (Меѓ другото, токму нејзината улога и функција како фалусна мајка го препокрива и сокрива нејзиниот статус како жена, нејзината сексуална разлика од синот.) Тој мора да ја порекне мајчинската кастрираност доколку сака да се заштити себеси од можноста за неговата сопствена кастрираност. Фетишот е негово поклонение кон исчезнатиот мајчински фалус, негов начин и да го заштити неговото верување во него и истовремено да ја прифати нејзината кастрираност a, со тоа, и возможноста од сопствената:

Да, во неговиот ум жената добила пенис, и покрај сё; но, овој пенис не е веќе истиот каков што бил претходно. Нешто друго го зазело неговото место и било назначено за негов супститут... и сега тоа го наследува интересот кој првично бил насочен кон неговиот претходник. Но, овој интерес исто така претрпува несекојдневен растеж, затоа што хоророт од кастрирањето себеси си поставил споменик при создавањето на овој супститут. (Freud, 1927: 1954)
[The fetish] remains a token of triumph over the threat of castration and a protection against it. It also saves the fetishist from becoming a homosexual, by endowing women with the characteristic which makes them tolerable as sexual objects.... What other men have to woo and make exertions for can be had by the fetishist with no trouble at all. (Freud, 1927: 154)

Ironically, then, the fetishist is the least likely of analysands to enter a psychoanalytic contract. He remains perfectly happy with his love object (an object unlikely to resist his wishes and fantasies). In all likelihood, if he enters analysis at all, it will be at someone else's request. The fetish is a substitute for, a talisman of, the phallus, but not just any old phallus. For the preOedipal boy, the most valued ofphalluses is not his own (for his pre-Oedipal, imaginary penis is not yet elevated to the function of phallus), but his mother's-the phallus, that is, that endows her with power and authority. (Incidentally, it is precisely her role and function as phallic mother that covers over and hides her status as a woman, her sexual difference from the son.) $\mathrm{He}$ must disavow maternal castration if he is to protect himself against the possibility of his own castration. The fetish is his homage to the missing maternal phallus, his way of both preserving his belief in it and at the same time accepting her castration and, with it, the possibility of his own:

Yes, in his mind the woman has got a penis, in spite of everything; but this penis is no longer the same as it was before. Something else has taken its place, has been appointed its substitute... and it now inherits the interest which was formerly directed to its predecessor. But this interest suffers an extra-ordinary increase as well, because the horror of castration has set up a memorial to itself in the creation of this substitute. (Freud, 1927: 154) 
Фетишот едноставно не може да биде еквивалент на мајчиниот или женскиот пенис затоа што тој и ја потврдува $и$ ја одрекува кастрираноста на жените. Не постои симболичко равенство помеѓу фетишот и пенисот бидејќи, како што толку убедливо образлага Лакан, фалусот не е еквивалент на пенисот (токму поради ова фалусот на мајката е најзначајниот во еротскиот живот на детето). Односот помеѓу фалусот и фетишот е веќе сосема тесно поврзан со поредокот на означителите. Пенисот (како реален орган) може да се нафати на улогата на фалусот само затоа што тој недостасува, т.е., затоа што жените се кастрирани. И двата термина потврдени и одречени како еквивалентни се означители; во ниеден момент (Лакановото) Реално не влегува во равенството. Лакан сугерира дека Фројдовиот случај на младиот човек со фетиш за светнати носови (Freud, 1927) може да биде објаснет само во смисла на преместување зачнато во јазикот, преместување од еден означител кон друг, преод од англиското "glance at the nose" кон германското "Glanz auf der Nase". Пенисот, во онаа мерка во која е замислуван како издвоив, како нешто што мајката го „има“ и може да го „изгуби" - е исто толку претстава, означител, како и фалусот. Фетишот е (во најмала рака) третиот израз во оваа метонимска верига:

Ние сме сега во една димензија каде што се чини дека се загубило значењето, димензија каде што може да се најде, очевидно, фетишистичката перверзија, склоноста кон светнати носови. И, ако немаше никакво образложение за носот... ова би било исто толку невозможно да се анализира колку и вистинската перверзна фиксација. Навистина, ако папучата беше, строго говорејки, преместување на женскиот орган и ниеден друг елемент не беше присутен за образложување на примарните податочи, ние ќе сметавме дека сме соочени со примитивна перверзија комплетно вон досегот на анализата. (Lacan and Granoff, 268-69) ${ }^{5}$

Фетишот е наследник на сите амбивалентности и на неопределеноста на ставот на момчето кон мајчината кастрираност. Славната студија на случај на Шандор Лоранд за фетишистот Литл Хари го опишува Хари како ги гали чевлите на неговата мајка и на самиот Лоранд, притоа
The fetish cannot simply be equivalent to the maternal or female penis because it both affirms and denies women's castration. There is no symbolic equation between the fetish and the penis because, as Lacan so cogently argues, the phallus is not the equivalent of the penis (this is why the mother's phallus is the most significant one in the child's erotic life). The relation between phallus and fetish is already entirely bound up with the order of signifiers. The penis (as real organ) can only take on the role of the phallus because it is missing, i.e., because women are castrated. The two terms affirmed and denied as equivalent are both signifiers; at no point does the (Lacanian) Real enter the equation. Lacan suggests that Freud's case of the young man with a fetish for shiny noses (Freud, 1927) can only be explained in terms of a displacement initiated in language, a displacement from one signifier to another, a shift from the English "glance at the nose" to the German "Glanz auf der Nase." The penis, insofar as it is conceived as detachable, as something the mother "has" and can "lose"-is as much a representation, a signifier, as the phallus. The fetish is (at the least) the third term in this metonymic chain:

We are now in a dimension where meaning seems lost, the dimension where is to be found, apparently, the fetishist perversion, the taste for shiny noses. And, if there were no elaboration upon the nose... this would be as impossible to analyse as a true perverse fixation. Indeed, if a slipper were, strictly speaking, the displacement of the female organ and no other elements were present to elaborate primary data, we would consider ourselves faced with a primitive perversion completely beyond the reach of analysis. (Lacan and Granoff, $268-69)^{5}$

The fetish is heir to all the ambivalences and the indeterminacy of the boy's attitude toward maternal castration. Sandor Lorand's famous case study of the fetishist Little Harry describes Harry caressing the shoes of his mother and ofLorand himself, while also exhibiting impulses to cut them. His whole symptoma- 
пројавувајќи нагони да ги исече. Целокупната негова симптоматологија е препознатлива по истата амбивалентност што го карактеризира неговиот однос кон мајчиниот фалус. Момчето има голем пред-Ојдиповски пристап до телото на мајката, спиејќи со неа во ист кревет и после тригодишна возраст (Lorand, 423). Тоа знае дека нејзиниот сексуален орган не е ист како и неговиот. Сепак, тоа порекнува било какво знаење за гениталните разлики за да ја одбие кастрационата закана, која ја перципира како да е насочена кон неговиот орган. Не само што тоа гали и сече чевли, тоа исто така развива фобија кон часовници со нишала (кои што го потсетуваат на докторовиот хируршки зафат кога имало операција на фимоза на двегодишна возраст); тоа опсесивно ги сече кадрите од сопствената коса без да знае зошто (422); и, што е најнеобично, кај него се развива смртен страв од ампутирани: „...семејството дошол да го посети некој роднина, човек со една ампутирана нога. Хари не можел да биде наведен да влезе во собата; во моментот кога го слушнал гласот на човекот надвор од вратата тој почнал да вреска во спалната...“ (422). Хари и ја потврдува и ја одрекува, истовремено ја допушта и одбива да ја прифати, возможноста од сопствената кастрираност. Фетишот (на пример, преокупираноста на Хари со чевлите или зависноста на Фројдовиот пациент од светнатиот нос) функционира само како знак врз основа на неговото упатување на фалусот, а не на пенисот.

Пенисот мора веќе да функционира како означител, имагинарен објект, од моментот кога момчето иे го припишува на мајката. Фетишот не е претстава на пенисот како што ниту пората на кожата не може да ја претставува вагината. Перцепцијата на детето на мајчиниот недостаток, и неговото симболичко користење како последен здогледан објект пред тоа да го види недостасувачкиот фалус - чевлите, женските чорапи, долната облека, крзното, итн. - адекватно не го објаснуваат фетишизмот бидејќ фетишот е супститут за фалусот. Пенисот ја презема функцијата на фалусот затоа што тој е белег или трага што исклучува барем половина од населението. Од реален орган, пенисот е трансформиран во имагинарен објект кој што ги tology is marked with the same ambivalence that characterizes his relation to the mother's phallus. The boy has ample preOedipal access to the mother's body, having slept in the same bed with her until he was over three (Lorand, 423). He knows that her sexual organ is not the same as his own. Yet he disavows any knowledge of genital differences in order to stave off the castration threat, which he perceives being directed to his own organ. He not only caresses and cuts shoes, he also develops a phobia about pendulum clocks (which remind him of the doctor's surgery when he had an operation for phymosis at the age of two); he obsessively cuts locks of his own hair without knowing why (422); and, most particularly, he develops a mortal dread of amputees: "...a relative came in to visit the family, a man with one leg amputated. Harry could not be induced to enter the room; the moment he had heard the voice of the man outside the door he ran screaming into the bedroom..." (422). Harry both affirms and denies, both acknowledges and refuses to accept, the possibility of his own castration. The fetish (for example, Harry's preoccupation with shoes or Freud's patient's dependence on the shiny nose) only functions as a sign by virtue of its reference to the phallus, not the penis.

The penis must already function as a signifier, an imaginary object, from the moment the boy attributes it to the mother. The fetish is not a representation of the penis any more than a pore of the skin can represent the vagina. The child's perception of the mother's lack, and his symbolic utilization of the last object witnessed before he "sees" the missing phallus-shoes, stockings, underwear, fur, etc.- do not adequately explain fetishism because the fetish is a substitute for the phallus. The penis takes on the function of the phallus only because it is a mark or trace that excludes at least half the population. From being a real organ, the penis is transformed into an imaginary object dividing the sexes according to its presence or absence, possessed by some and desired by others. Only then can it 
дели половите според неговото присуство или отсуство, поседуван од едните а посакуван од другите. Само тогаш тој може да функционира како симболички објект (објект на сојуз/размена) помеѓу половите. Фалусот го расподелува пристапот до социјалните категории овластени со различни односи на моќ: „Тој е врвниот значенски објект кој што се појавува кога ќe се симнат сите превези. Сѐ што е поврзано со него е објект на ампутации и пресекувања" (Lacan, 1977a: 104). Kora ḱе се симне превезот останува само Медузата, женините кастрирани гениталии, недостатни, непотполни, ужаснувачки (за мажите). Танцот на Саломе, како стриптиз, може да заведува само кога барем еден превез останува, намамувајќи, а сепак прикривајќи ја ништожноста на полот на жените. На тој начин фетишот ја игра улогата на превез, истовремено истакнувајќи ја, а сепак препокривајќи ја, кастрираноста на жените.

\section{Порекнување}

Фројд ги припишува особеностите на фетишизмот на неговото потпирање врз психичкиот одбранбен механизам на порекнувањето. Порекнувањето мора да се разграничува од другите три главни форми на психичка одбрана; потиснувањето (врутокот на неурозата), негацијата или одрекувањето, и отстранувањето или пренебрегнувањето (главниот механизам кој функционира при генезата на психозата). За да го разбереме она што му е својствено само на фетишизмот и зошто Фројд го ограничи само на маскулинистичкиот развој, пожелно е малку поподробно да ги истражиме овие одбранбени механизми.

Негацијата е провизорно ослабување на потиснувањето, во услови кога потиснатите содржини се вербално и афективно негирани: „[Негацијата] е исто така ослабување на потиснувањето иако се разбира не и прифаќање на она што е потиснато... Исходот од ова е еден вид интелектуално прифаќање на потиснатото, иако во исто време она што е суштествено за потиснувањето опстојува“ (Freud, 1925: 236). Во негацијата, има една афирмација на она што е потиснато: за некој да негира или одрекува неш- function as a symbolic object (an object of union/exchange) between the sexes. The phallus distributes access to the social categories invested with various power relations: "It is the ultimately significative object which appears when all the veils are lifted. Everything related to it is an object of amputations and interdictions" (Lacan, 1977a: 104). When the veil is lifted there is only the Medusa, women's castrated genitals, lacking, incornplete, horrifying (for men). Salome's dance, like striptease, can only seduce when at least one veil remains, alluring, yet hiding the nothing of women's sex. The fetish thus plays the role of the veil, both outlining and yet covering over women's castration.

\section{Disavowal}

Freud attributes the peculiarities of fetishism to its reliance on the psychical defence mechanism of disavowal. Disavowal must be distinguished from three other major forms of psychical defense; repression (the mainspring of neurosis), negation or denial, and repudiation or foreclosure (the major mechanism functioning in the genesis of psychosis). In order to understand what is unique about fetishism and why Freud restricted it to masculine development, it is worth exploring these defense mechanisms in a little more detail.

Negation is a provisional lifting of repression, on the condition that the repressed contents are verbally and affectively negated: "[Negation] is also a lifting of repression, though not of course an acceptance of what is repressed.... The outcome of this is a kind of intellectual acceptance of the repressed, while at the same time what is essential to the repression persists" (Freud, 1925: 236). In negation, there is an affirmation of what is repressed: to negate or deny something one must have previously affirmed it. Affirmation is the process of registering or 
то мора претходно истото да го афирмирал. Афирмацијата е процесот на забележување или фиксирање на поривот врз идеационата содржина, означувајќи го првото со второто. Афирмацијата е ем услов за означување и потиснување - нешто мора да биде означено пред да биде деградирано во несвесното - ем враќґе на потиснатото. Едноставно додавајќи едно „не" на афирмацијата, негацијата допушта свесно забележување на потиснатата содржина и го одбегнува цензорството. Таа е многу економичен начин на психичка одбрана, прифаќајќи ги несвесните содржини под услов тие да се одречени.

Отстранувањето подразбира отфрлање на некоја идеја која еманира од надворешната реалност а не од идот. Тоа е неуспех да се регистрира некој впечаток, кој подразбира отфрлање на дел од реалноста или одлепување од него:

Егото создава, автократски, нов надворешен и внатрешен свет.... [О]вој свет е конструиран во согласност со желбените пориви на идот, и ... мотивот за ова дисоцирање од надворешниот свет е некоја многу сериозна фрустрација од реалноста на некоја желба - фрустрација што се чини неподнослива. Тесната поврзаност на оваа психоза со нормалните соништа е непогрешлива. (1924: 151).

Психотичката халуцинација не е е враќање на потиснатото т.е., враќање на означителот, туку враќње на реалното кое никогаш не било означено - пренебрегнувачка или скотомизирана перцепција, нешто што паѓа врз субјектовата слепа точка. Субјектовата перцепција не е проектирана нанадвор врз надворешниот свет. Поскоро, она што е внатрешно прикриено повторно му се појавува на субјектот како да еманира од Реалното, попрво во халуцинаторна одошто во проективна форма. Тоа се соочува со субјектот од една независна, надворешна позиција.

Порекнувањето е некаде на полпат помеѓ овие физички одбрани. Како и потиснувањето и негирањето, тоа подразбира физичко регистрирање на некој нагон, најизразито Ојдиповскиот нагон; но, како и пренебрегнувањето или отстранувањето, тоа ги отфрла содржините на fixing a drive to an ideational content, signifying the former by the latter. Affirmation is both the condition of signification and of repression-something must be signified before it can be relegated to the unconscious-and the return of the repressed. By simply adding a "no" to the affirmation, negation allows a conscious registration of the repressed content and avoids censorship. It is a very economical mode of psychical defense, accepting unconscious contents on the condition that they are denied.

Repudiation involves the rejection of an idea that emanates from external reality rather than from the id. It is a failure to register an impression, involving a rejection of or detachment from a piece of reality:

The ego creates, autocratically, a new external and internal world.... [This world is constructed in accordance with the id's wishful impulses, and...the motive of this dissociation from the external world is some very serious frustration by reality of a wish-a frustration which seems intolerable. The close affinity of this psychosis to normal dreams is unmistakable. (1924: 151)

The psychotic's hallucination is not the return of the repressed, i.e., the return of a signifier, but the return of the Real that has never been signified-a foreclosed or scotomized perception, something falling on the subject's psychical blind spot. The subject's perception is not projected outward onto the external world. Rather, what is internally obliterated reappears for the subject as if it emanates from the Real, in hallucinatory rather than projective form. It confronts the subject from an independent, outside position.

Disavowal exists somewhere mid-way between these psychical defences. Like repression and negation, it involves the psychical registration of an impulse, most notably the Oedipal impulse; but, like foreclosure or repudiation, it refuses the contents of a perception or a piece of reality. It does not rely 
перцепцијата или дел од реалноста. Тоа не се потпира на несвесното ниту пак го ползува. Тоа му преследува на востановувањето на несвесното и, како и отфрлањето, подразбира расцеп во егото. За разлика од психозата, порекнувањето не подразбира неуспех на претставувањето, затоа што тоа е плодоносно во претставувачки поглед. Неговата структура е всидрена од детското прифаќање на реалноста и неговото истовремено одбивање на реалноста, што го раѓa нагонот за произведување раскошни значенски контексти и фантастични сценарија.

Фетишистот не отстапува од две стојалишта при порекнувањето: одрекувањето на недостатокот на жените и неговото признавање и прифаќање. Двете стојалишта „опстојуваат напоредно за време на нивниот живот без да си влијаат едносодруго. Тука може со' гіраво да се каже дека имаме расцепување на егото“ (Freud; 1940: 276). За разлика од потиснувањето, каде што егото потиснува претставник на идот, при порекнувањето два дела на егото користат противречни форми на одбрана. На овој начин фетишот, како супститут за мајчиниот фалус, ја потврдува и одрекува кастрираноста на жените. Фетишистот е на полпат помеѓу неуроза и психоза: тој се заштитува себеси од психоза претставувајќи го мајчиниот фалус преку фетишистичката супституција, притоа тој е заштитен од неуроза преку неговото потиснување на кастрационата закана. Тоа е како едниот дел од егото (што ја прифаќа кастрираноста) да е неуротичен, а другиот дел (што ја отфрла кастрираноста) да е психотичен.

Која е главната разлика помеѓу психотичарот и фетишистот ако и обајцата споделуваат порекнување и отфрлање на дел од реалноста? Разликата изгледа лежи во противставеноста на халуцинацијата и супституцијата. Фетишистот „едноставно не им противречи на неговите перцепции и халуцинира пенис таму каде што ништо такво не може да се види, тој не направил ништо друго освен преместување на вредност - тој ја пренел важноста на пенисот на друг дел од телото (1940: 277). Ова преместување на вредност од пенисот на друг дел од телото или врз некој нежив објект ќе стане клучно во следнава upon or utilize the unconscious. It predates the establishment of the unconscious, and, like repudiation, involves a split in the ego. Unlike psychosis, disavowal does not involve a failure of representation, for it is remarkably prolific in representational means. Its structure is anchored by the child's acceptance of reality and its simultaneous refusal of reality, which generate the impulse to produce profuse significatory contexts and fantasy scenarios.

The fetishist maintains two attitudes in disavowal: the denial of women's lack and its recognition and acceptance. The two attitudes "persist side by side throughout their lives without influencing each other. Here is what may rightly be called a splitting of the ego" (Freud, 1940: 276). Unlike repression, where the ego represses a representative of the id, in disavowal two parts of the ego utilize contradictory forms of defense. In this way the fetish, as a substitute for the maternal phallus, affirms and denies women's castration. The fetishist is midway between neurosis and psychosis: he preserves himself from psychosis by representing the maternal phallus through fetishistic substitution, yet he is saved from neurosis by his repression of the castration threat. It is as if one part of the ego (which accepts castration) is neurotic, and the other part (which repudiates castration) is psychotic.

What is the major difference between the psychotic and the fetishist if both share disavowal and rejection of a piece of reality? The difference seems to lie in the opposition between hallucination and substitution. The fetishist "did not simply contradict his perceptions and hallucinate a penis where there was none to be seen, he effected no more than a displacement of value-he transferred the importance of the penis to another part of the body" (1940: 277). This displacement of value from the penis to another part of the body or onto an inanimate object will become crucial in the following discussion of the possibility of female fetishism, and particularly lesbian fetishism. 
расправа за возможноста на женски фетишизам, а особено на лезбејски фетишизам.

\section{Фетишизмот и женственоста}

Зошто женскиот фетишизам е оксиморон (Schor, 365)? Врз основа на Фројдовото објаснување, женскиот фетишизам не е возможен затоа што девојката нема никаков разлог или мотив за да ја порекне кастрираноста на мајката. Порекнувањето нема да ја заштити од спознавањето на сопствената кастрираност како што може во случајот со момчето. За разлика од кастрираноста што му се заканува или е возможна кај момчето, девојката веќe била кастрирана и нејзината задача е пасивна, прифаќање на нејзиниот статус. Порекнувањето кај девојките воопшто не е невообичено, но нема никаква смисла за неа да ја порекнува кастрираноста на мајката. Наместо тоа, таа настојува да ја порекне сопствената кастрираност. Навистина, од страна на девојката, ова е совршено "нормална" прва реакција на идејата за нејзината кастрираност.

Фројдовата позиција е главно прифатена од страна на современите психоаналитички теоретичари, дури и кога има известување за случаи на женски фетишизам. $\mathrm{Ha}$ пример, Џулиет Хопкинс го опишува случајот на шестгодишното женско дете кај кое се појавува фетиш за стапала и чевли. Девојчето имало необичен фетишистички предмет, табакера, што „ја користела исклучиво за сексуални цели... кога мастурбирала" (Hopkins, 82). Меѓутоа, она што му подлежи на фетишизмот на девојчето (и веројатно го објаснува) е формата на психоза во која „девојчето верувало за себеси дека е момче" (83). Хопкинс упатува на тврдењето на Филис Гринакр дека „симптомите на фетишизам се јавуваат само кај женски лица кај кои илузорниот фалус се здобил со таква моќ која се приближува до привидувачкото" (83); односно, фетишизмот е можен кај женски лица кои за себе веруваат дека се машки. Шор исто така цитира четири случаи на женски фетишизам, но сите тие изгледа на сличен начин покажуваат силна идентификација на девојката со фалусната маскулина позиција. Овие девојки се на граница на психоза бидејќи тие ја от-

\section{Fetishism and femininity}

Why is female fetishism an oxymoron (Schor, 365)? On Freud's account, female fetishism is not possible because there is no reason or motive for the girl to disavow the mother's castration. Disavowal will not protect her against the acknowledgement of her own castration as it might in the case of the boy. Unlike the boy's threatened or possible castration, the girl has already been castrated and her task is the passive one of accepting her status. Disavowal in girls is by no means uncommon, but it makes no sense for her to disavow the mother's castration. Rather, she tends to disavow her own castration. This is indeed the perfectly "normal" first reaction on the girl's part to the idea of her castration.

Freud's position is generally accepted by contemporary psychoanalytic theorists, even where there are reported cases of female fetishism. For example, Juliet Hopkins describes the case of a six-year-old female who develops a foot and shoe fetish. The girl had a particular fetish object, a tobacco tin, that "she used exclusively for sexual purposes... when she masturbated" (Hopkins, 82). Underlying the girl's fetishism, however, (and perhaps explaining it), was a form of psychosis in which "the girl believed herself to be a boy" (83). Hopkins refers to Phyllis Greenacre's claim that the "symptoms of fetishism only develop in females in whom the illusionary phallus has gained such strength as to approach the delusional" (83); that is to say, fetishism is possible in females who believe themselves to be male. Schor also cites four cases of female fetishism, but they all similarly seem to exhibit a strong identification of the girl with the phallic position of masculinity. These girls border on psychosis because they repudiate the psychical reality of castration rather than disavow it. They refuse their castrated condition and continue to believe in their own phallic position. They do not exhibit the ambivalence, the duplicity, of the fetishist's disavowal, 
фрлаат психичката реалност на кастрираноста наместо да ја порекнат. Тие не ја прифаќаат нивната кастрирана состојба и продолжуваат да веруваат во сопствената фалусна состојба. Тие не ја пројавуваат амбивалентноста, двојноста, на фетишистичкото порекнување, зашто нема истовремено потврдување и одрекување, такво што го спасува фетишистот од психоза.

За да разбереме зошто Фројд сметал дека е невозможно жените да бидат фетишисти, а притоа да разбереме дека лезбејството може да биде согледано како форма на женски фетишизам, ние треба да ги истражиме операциите на порекнување, и нивните последици врз женскиот развој. Има три одделни патеки што можат да произлезат од девојчиното порекнување на нејзината сопствена кастрираност: хетеросексуалниот (секундарен) нарцизам, хистеријата, и комплексот на маскулиност. Во „За нарцизмот: Увод" (1914), Фројд скицира низа објект-избори кои што му се отвораат на женствениот, или како што тој го нарекува, „нарцистички" тип. Тука женствениот субјект (без оглед дали е машки или женски) го сака објектот согласно на неговата сличност, истоветност, или поврзаност со себе. Фројд тврди дека, како вид на компензација за нејзиното признавање на нејзината инфериорност, девојката може да развие (секундарно) нарцистичко вложување во сопственото тело, третирајки го како што некое соодветно машко би третирало надворешен љубовен објект. Таа го размазува нејзиното тело, го третира со љубовна грижа; тоа станува витален инструмент, нејзино средство за осигурување дека таа е сакана. Тоа е исто така нејзи начин на развивање критериуми за мерење на нејзината сопствена вредност. Таа го фалицира целото нејзино тело. Ако мажот верува дека тој го има фалусот (објектот на желба), тогаш жената верува дека таа е фалусот. Машкиот пенис и целото женско тело се протолкувани како физички еквивалентни. Лакановски кажано, тој го има објектот на желбата додека таа е објектот на желбата.

Во процесот на себепретворање во објект на желба, нарцистичката жена ја преместува вредноста на фалусот for there is no simultaneous affirmation and denial of the kind which saves the fetishist from psychosis.

In order to understand why Freud considered it impossible for women to be fetishists, and yet to understand that lesbianism could be seen as a form of female fetishism, we need to explore the operations of disavowal, and its effects on feminine development. There are three distinctive paths which may result from the girl's disavowal of her own castration: heterosexual (secondary) narcissism, hysteria, and the masculinity complex. In "On Narcissism: An Introduction" (1914), Freud outlines a series of object-choices open to the feminine or what he calls the "narcissistic" type. Here the feminine subject (whether male or female) loves an object according to its resemblance, identity, or connection with the self. Indeed, Freud claims that, as a kind of compensation for her recognition of her inferiority, the girl may develop a (secondary) narcissistic investment in her own body, treating it as the corresponding male would an external love-object. She pampers her body, treats it with loving care; it becomes a vital instrument, her means of ensuring that she is loved. It is also her way of developing criteria for measuring her own self-worth. She phallicizes her whole body. If man believes he has the phallus (the object of desire), then woman believes she is the phallus. The man's penis and the whole of the woman's body are rendered psychically equivalent. In Lacanian terms, he has the object of desire while she is the object of desire.

In the process of making herself the object of desire, the narcissistic woman displaces the value of the phallus onto 
на сопственото тело, земено во целина. Значи, таа го има фалусот, само во онаа мерка во која таа е фалусот (за некој кој ја љуби или посакува). Оваа таканаречена „нормална“ патека на женственоста, компензирањето (и на тој начин прифаќањето) на нејзината кастрираност, подразбира компензационо фалицизирање на нејзиото тело. Во оваа смисла, „нарцистичката жена" е последица на функцијата на фалусот во конституирањето на сексуалниот идентитет. Нарцистичката жена, наспроти карактеризирањето на Кофман, е далеку од тоа да биде независна и автономна. Таа се стреми да ја зачува нејзината позиција како објект на желбата на другиот само со умешност, изглед, или прикривање.

Илузијата, травестијата, шминката, намамувањето, се техниките на кои таа се потпира и за да ги прикрие и за да ги обелодени нејзините „суштински предности“. Тие се нејзиното средство за заведување или намамување на маскулиниот или анаклитичкиот љубовник, за да стане негов љубовен објект. Додека вака, со овие средства ја затскрива нејзината „непотполност“, таа обезбедува начин на пристап до фалусното. Иронично е тоа што во оваа заложба за станување фалус, објект на желбата на другиот, таа е откриена како место на расцеп, недостаток, или кастрираност, и идеализирано и понижено, омегено со маскарадата на женственоста, место и на изобилство и на недостаток: „Колку и да изгледа парадоксално оваа формулација, велам дека за да стане фалусот, односно, означителот на желбата на Другиот, жената ќе отфрли суштествен дел од женственоста, имено, сите нејзини атрибути во маскарадата" (Lacan 1977a: 289-290).

Ако нарцистичката жена спроведе фалусирање на целото нејзино тело тогаш, во извесна смисла, таа ги доведува до крајност стратегиите користени од хистерикот. Хистеријата е специфично феминина неуроза во која, преку соматското угодување на еден дел од телото, „хистеричната зона", сексуалноста на субјектот е во состојба да биде преместена. Како и нарцистичката жена, хистеричната ја прифаќа нејзината кастрирана позиција; но, за разлика од нарцистичката, нејзиното вложување не е во фа- her own body, taken as a whole. She has the phallus, then, only inasmuch as she is the phallus (for someone who loves or desires her). This so-called "normal" path of femininity, the compensation for (and thus acceptance of) her castration, involves the compensatory phallicization other body. In this sense, "the narcissistic woman" is an effect of the function of the phallus in the constitution of sexual identity. The narcissistic woman, contrary to Kofman's characterization, is far from independent and autonomous. She strives to retain her position as the object of the other's desire only through artifice, appearance, or dissimulation.

Illusion, travesty, makeup, enticement become techniques she relies on to both cover and make visible her "essential assets." They are her means of seducing or enticing the masculine or anaclitic lover, becoming a love-object for him. While thus concealing her "deficiency" by these means, she secures a mode of access to the phallic. Ironically, in this aim of becoming the phallus, the object of the other's desire, she is revealed as the site of rupture, lack, or castration, both idealized and debased, bound up with the masquerade of femininity, the site of both excess and deficiency: "Paradoxical as this formulation may seem, I am saying that it is in order to be the phallus, that is to say, the signifier of the desire of the Other, that a woman will reject an essential part of femininity, namely, all her attributes in the masquerade" (Lacan, 1977a: 289-290).

If the narcissistic woman effects a phallicization of the whole of her body, then in a sense she takes to one extreme the strategies utilized by the hysteric. Hysteria is a specifically feminine neurosis in which, through a somatic compliance of a part of the body, the "hysterogenic zone," the subject's sexuality is able to be displaced. Like the narcissistic woman, the hysteric accepts her castrated position; but unlike the narcissist, her investment is not in a phallic subject who, through his desire, can bestow on her the position of being the phallic object. The 
лусниот субјект кој, преку својата желба, може да иे ја додели нејзе позицијата да биде фалусен објект. Хистерикот ја одбегнува маскулината желба, наместо неа претпочитајќи ја сега загубената пре-Ојдиповска приврзаност кон нејзината мајка (или супститутите на мајка). Бунтувајќ се против пасивноста обично асоцирана со женственоста, таа хистеризира - односно, го фалусира - не целото нејзино тело, туку хистеричната зона. Можеме да ја земеме како пример Дора: Таа го преместува гениталното задоволство во извесна форма на хистерично гушење. Во низи од инфантилни идентификации (во однос на кои се чини Фројд е збунет или премногу преокупиран) таа го фалусира нејзиниот грклан и го користи за да го сигнализира своето гнасење од сексуалните предности на Хер К. Таа го хистеризира овој дел од нејзиното тело како извесна форма на носталгија, споменик за нејзината мајчинска пред-историја, кој таа мора (но одбива) да го отфрли во замена за законот на таткото. Таа не го задржува клиторисот (како во маскулиниот комплекс), ниту пак таа го пренесува сексуалниот интензитет врз вагината (како што е случај со „нормалната“, т.е., хетеросексуална женственост; сега нејзиното либидо е вложено во не-генитална зона.

Разликата помеѓу хистеричната и нарцистичката жена е разлика помеѓу преместувањето на фалусот врз некој дел или врз целото тело на субјектот (можеби повеќе разлика во степен отколку во вид?). Додека кај нарцисистичката жена целото тело е фалус (и оттаму нејзе иे треба надворешен љубовен објект за да й го додели статусот на објект на желба, што го објаснува нејзиното потпирање на анаклитичкиот љубовник, без оглед дали е хетеросексуален или хомосексуален), хистеричната жена стекнува самодефиниран статус како фалусна: дел од нејзиното тело ја презема функцијата на фалусот (потврдувајќи го нејзиниот статус како предмет во патријархатот), а пак нејзината субјективност останува во активна положба (таква која го смета нејзиното сопствено тело како свој објект).

Значи, порекнувањето во никој случај не е својствено само на мажите; тоа е одбранбен механизам достапен и расположлив за жените. Неговите операции нужно hysteric eschews masculine desire, preferring instead the now lost pre-Oedipal attachment to her mother (or mother-substitutes). In rebelling against the passivity usually associated with femininity, she hystericizes-that is to say, phallicizes-not the whole of her body, but a hysterical zone. We can take Dora as an example: She displaces genital pleasure into a form of hysterical choking. Through a series of infantile identifications (about which Freud seems rather confused or over-invested) she phallicizes her throat and uses it to signal her disgust at Herr K's sexual advances. She hystericizes this part of her body as a form of nostalgia, a monument to her maternal pre-history, one she must (but refuses to) abandon in exchange for the father's law. She does not retain the clitoris (as in the masculinity complex), nor does she transfer sexual intensity to the vagina (as occurs in "normal," i.e., heterosexual femininity); her libido is now invested in a non-genital zone.

The difference between the hysteric and the narcissist is the difference between the displacement of the phallus onto a part or onto the whole of the subject's own body (perhaps a difference of degree rather than kind?). Whereas the narcissist's whole body is the phallus (and thus she requires an external love object to bestow on her the status of the object of desire, accounting for her reliance on an anaclitic lover, whether heterosexual or homosexual), the hysteric gains a self-defined status as phallic: a part other own body takes on the function of the phallus (confirming her object-like status in patriarchy), while her subjectivity remains in an active position (one which takes her own body as its object).

Disavowal, then, is by no means unique to men; it is a defense mechanism open and available to women. Its operations do not necessarily signal psychosis, but may function as a 
не сигнализираат психоза, туку можат да функционираат како форма на заштита, иако не - како во случајот со момчињата - против можната загуба, туку поскоро против личното понижување и трансформирањето на нејзиниот статус од субјект во објект, од активна во пасивна, и од "фалусна" во „кастрирана" - Фројдовата „дефиниција" на женскоста. Тоа е стратегија на самозаштита, дури и ако имплицира некаков вид одлепување од социо-симболичката „реалност“.

Третиот особен исход од девојчиното порекнување на нејзината кастрираност е она што Фројд го нарекува „маскулин комплекс“. Девојката што „страда“ од таков комплекс одбива да го прифати својот секундарен и субординиран статус; таа претендира да биде третирана и да постапува исто како мажите. Фројд сугерира дека иако маскулиниот комплекс нужно не мора да имплицира лезбејство, сепак многу лезбејки можат да се класификуваат под оваа етикета. Онаму каде што таканаречената нормална патека на женскоста подразбира прифаќање на нејзината кастрираност и пренесување на нејзината либидна катхесис од мајката на таткото (vіа пенисната завист), со придружната трансформација на нејзиниот водечки сексуален орган од клиторисот кон вагината (и со неа поврзаната положба на пасивност), жената што страда од маскулиниот комплекс го задржува клиторисот како нејзин водечки сексуален орган и положбата на активност што тој ја подразбира. Таа исто така може да го задржи мајчинскиот лик како модел врз кој ќе ги засновува нејзините подоцнежни приврзаности кон објекти, продолжувајки во тој случај да сака жена супститут на мајка: „Така девојката може да одбие да го прифати фактот дека е кастрирана, може да се очеличи себеси со убедувањето дека таа навистина поседува пенис и следствено може да биде принудена да се однесува божем таa е маж" (Freud, 1925a: 253).

Навистина, токму на ваков начин Фројд ја објаснува женската хомосексуалност во оние ретки пасуси и текстови каде што тој, благо речено, упатува на лезбејството. Во случајот на неименуваната хомосексуална жена (Фреуд, 1920), тој ја опишува неа дека се однесува како галантен form of protection, though not- as in the case of boys-against potential loss, but rather against the personal debasement and the transformation of her status from subject to object, active to passive, and "phallic" to "castrated"- Freud's "definition" of femininity. It is a strategy of self-protection, even if it implies a certain mode of detachment from socio-symbolic "reality."

The third distinctive effect of the girl's disavowal of her castration is what Freud calls the "masculinity complex." The girl "suffering" from such a complex refuses to accept her secondary and subordinated status; she aspires to be treated like and to act the same as men. Freud suggests that although the masculinity complex may not necessarily imply lesbianism, nevertheless many lesbians can be classified under this label. Where the so-called "normal" path to femininity involves accepting her castration and transferring her libidinal cathexes from the mother to the father (via penis envy), with the accompanying transformation other leading sexual organ from the clitoris to the vagina (with its associated position of passivity), the woman suffering from the masculinity complex retains the clitoris as her leading sexual organ and the position of activity it implies. She may also retain the maternal figure as the model on which to base her later object attachments, in which case she will continue to love a female mother-substitute: "Thus the girl may refuse to accept the fact of being castrated, may harden herself in the conviction that she does possess a penis and may subsequently be compelled to behave as though she were a man" (Freud, 1925a: 253).

Indeed this is how Freud explains female homosexuality in those rare passages and texts when he refers to lesbianism at all. In the case of the unnamed female homosexual (Freud, 1920), he describes her as behaving like a chivalrous male lover, displaying many of the characteristics attributed to the anaclitic or 
машки љубовник, прикажувајќи повеќе карактеристики коишто му се припишуваат на анаклитичкиот или маскулин тип. Таа љуби „како маж“. Иако можеме да го оспоруваме овој опис како соодветен за сите видови лезбејски љубовни врски, се чини е јасно дека тој секако го опишува односот "буч"-,феме“ кој се чини дека ги умножува структурните позиции на патријархалната хетеросексуалност, разграничувајќи ја нарцистичката (женствена) љубовничка од анаклитичката (мажествена) љубовничка. Вторава овде ја порекнува нејзината кастрираност, додека првата ја прифаќа својата кастрираност но одбива да го претвори нејзиниот љубовен објект од мајчински во татковски.

Како и кај машката хомосексуалност, за психоанализата женската хомосексуалност главно презема една од двеве форми, засновани на една или друга насока на инфантилен развој. Во насоката што произведува маскулин комплекс, има порекнување на кастрираноста на жените и одбивање да се признаат социјално санкционираните значења на сексуалната разлика. Девојката ќе продолжи да се идентификува со фалусната мајка, дури може и да гледа во таткото просто уште едно отелотворување на фалусниот статус на мајката (значајно е дека ова е и судбината на машкиот фетишист, исто така). Но, одбивајки да ја признае својата разлика од фалусната позиција, таа ја задржува мажественоста од нејзината пред-Ојдиповска позиција и мајката како љубовен објект. Другата насока на женската хомосексуалност подразбира прифаќање на нејзиниот кастриран статус и привремено прифаќање на таткото како љубовен објект како во „нормалната" женственост; но, наместо пренесување на нејзината приврзаност од таткото на соодветниот машки супститут за таткото, девојката бара "фалусна“ жена, токму жена, како што може да се насети, со маскулин комплекс. Оваа пак копнее по женствен љубовен објект (како и мажите) иако првата копнее по мажествен љубовен објект (без оглед дали е машко или женско): ова може да биде опишано како хомсексуален еквивалент на комплементарната хетеросексуална поврзаност помеѓу анаклитичките и нарцистичките љубовни објекти. masculine type. She loves "like a man." While we may dispute this description as appropriate to all kinds ofles-bian love relationships, it seems clear that it certainly describes the butchfemme relation, which seems to replicate the structural positions of a patriarchal heterosexuality, distinguishing a narcissistic (feminine) lover from an anaclitic (masculine) lover. Here the latter disavows her castration, while the former accepts her castration but refuses to convert her love object from maternal to paternal.

As with male homosexuality, for psychoanalysis female homosexuality generally takes on one of two forms, based on one or the other path of infantile development. In the path that produces the masculinity complex, there is a disavowal of women's castration and a refusal to acknowledge the socially sanctioned meanings of sexual difference. The girl will continue to identify with the phallic mother, and may even see the father as simply another embodiment of the phallic status of the mother (it is significant that this is the fate of the male fetishist, as well). But refusing to acknowledge her difference from the phallic position, she retains the masculinity other pre-Oedipal position and the mother as love-object. The other path of female homosexuality involves an acceptance of her castrated status and the temporary taking on of the father as a love-object as in "normal" femininity; but, instead of transferring her attachment from the father to a suitable male father-substitute, the girl seeks out a "phallic" woman, a woman precisely, one may suspect, with a masculinity complex. The latter seeks a feminine love-object (as men do) while the former seeks a masculine love-object (whether male or female): this could be described as the homosexual equivalent of the complementary heterosexual association between anaclitic and narcissistic love-objects. 
Во каков однос е лезбејството со женскиот фетишизам? Во случајот на девојката која го има прифатено нејзиниот кастрационен комплекс, се чини дека е во мал или никаков однос. Но, случајот на жената што страда од маскулин комплекс може да сугерира извесна поврзаност. Како и фетишистот, таа ја порекнува кастрираноста на жените, но оваа кастрираност не е на нејзината фалусна мајка, туку нејзина. Исто како фетишистот, таа прифаќа супститут наместо фалусот, објект надвор од нејзиното тело. Токму ова е тоа што ја разликува неа од нарцисоидната и хистеричната жена, кои обете ги фалусираат или фетишизираат нивните сопствени тела, и кои всушност не ја зачувуваат фетишистичката структура на преместувањето на фалусната вредност од мајчиното тело вон некој објект надвор од некого. Наспроти ова, маскулината жена зема надворешен љубовен објект - друга жена - и преку овој љубовен објект е способна да функционира како таа да има, наместо да e, фалус. Како и кај фетишистот, ова имплицира расцепување на егото: ова е она што неа ја прави сколна кон самиот феминизам, во онаа мерка во која феминизмот, како кое и да е опозиционо политичко движење, подразбира порекнување на социјалната реалност, за промената да стане замислива и возможна.

Kora што фетишистот останува најзадоволен и најсреќен од сите перверти, маскулината жена останува најмалку среќна. Колку што таа се чувствува поеднаква или посупериорна во однос на мажите, толку помалку нејзината позиција како таква е социјално признаена, толку помалку нејзините убедувања се оправдувани од страна на другите, и толку поверојатно таа е повеќе социјално изопштувана. Таа ја преместува фалусната вредност врз објект надвор од мајчиниот (или нејзиниот сопствен) фалус; но, наспроти фетишистот, нејзиниот љубовен објект не е нежив или непотполн објект, туку тоа е друг субјект. Нејзиниот "фетиш“ не е резултат на стравот од женственост, туку на љубов; тој не ја заштитува неа од можната опасност, затоа што ја запознава со последиците од широко распространетата социјална хомофобија.
What relation does lesbianism have to female fetishism? In the case of the girl who has accepted her castration complex, there seems to be little or no relation. But in the case of the woman suffering from the masculinity complex, it may be possible to suggest some connection. Like the fetishist, she disavows women's castration, but this castration is her own, not that of the phallic mother. And like the fetishist, she takes on a substitute for the phallus, an object outside her own body. It is this which differentiates her from the narcissist and the hysteric, both of whom phallicize or fetishize their own bodies, and not really preserving the fetishistic structure of the displacement of phallic value from the mother's body to an object outside of one's self. By contrast, the masculine woman takes an external love-object-another woman-and through this love-object is able to function as if she has, rather than is, the phallus. As with the fetishist, this implies a splitting of the ego: it is this which inclines her to feminism itself, insofar as feminism, like any oppositional political movement, involves a disavowal of social reality so that change becomes conceivable and possible.

Where the fetishist remains the most satisfied and contented of all perverts, the masculine woman remains the least content. The more equal-or superior-to men she feels, the less her position is socially acknowledged as such, the less her convictions are validated by others, and presumably the more she is socially ostracized. She displaces phallic value onto an object outside the mother's (or her own) phallus; but, in contrast to the fetishist, her love-object is not an inanimate or partial object, it is another subject. Her "fetish" is not the result of a fear of femininity, but a love of it; it does not protect her from potential danger, for it introduces her to the effects of widespread social homophobia. 
Што треба да се постигне со опишувањето на овој облик на женска хомосексуалност како фетишистичка? Мене ова не ми е сосема јасно, и токму поради овој разлог мојот одговор мора да остане стратешки. Како и фетишистот, јас сакам да кажам и дека таа е или би можела да биде согледана во рамките на фетишизмот, и истовремено, дека таа не е. Она што за мене овде е на коцка, во оваа амбивалентност, е токму структурата на самата психоанализа: Во онаа мерка во која може да се каже дека психоанализата нуди реални увиди за жените општо земено, или за лезбејките, посебно во патријархалното општество, ние треба да ги растегнеме Фројдовите изрази за да покажеме дека самите тие не ги исклучуваат или дискриминираат жените - дека жените се третирани со историска прецизност која ги зема предвид нивните разни социјални позиции. Во онаа мерка во која психоанализата може да се согледува како активен учесник во патријархалните социјални вредности, ние треба да покажеме како нејзините изрази адекватно не ги доловуваат особеностите на жените, и нивните разлики од мажите.

Секако дека категориите што ги предложи Фројд како универзално релевантни - функцијата на фалусот, Ојдиповиот комплекс, сеприсутноста на кастрационата закана, и статусот на жените како пасивни - треба да бидат оспорени за да можат да се трансформираат самите општествени односи. Изборот што им стои на располагање на феминистичките теоретичар(к)и е или да ја прифатат психоанализата речиси на големо (што имплицира ставање во загради на политичките прашања покренати од патријархалните односи на моќ); или сосема да ја отфрлат (во тој случај останувајќи без објаснување на психичкиот живот и на фантазијата); или пак по малку од обете (фетишистичко решение), посебно одбирајки поим за кој се верува дека е невозможен или запоставен од теоријата за да покажат како истиот не е толку неверодостоен како што се чини, ако самите изрази се протегнат зад нивните нормални ограничености. Накусо, со развивање на парадокси и противречности за да се види како самата теорија се справува (или не се справува) со нејзините неизречени претпоставки или непризнаени импликации.
What is to be gained by describing this form of female homosexuality as fetishistic? This is not entirely clear to me, and it is for this reason that my answer must remain strategic. Like the fetishist, I want to say both that she is or could be seen in terms of fetishism, and at the same time, that she is not. At stake for me here, in this ambivalence, is the very structure of psychoanalysis itself: Insofar as psychoanalysis may be said to offer real insights about women in general or lesbians in particular in patriarchal society, we need to stretch Freud's terms in order to show that in themselves they do not exclude or discriminate against women-that women are treated with historical accuracy as to their various social positions. Insofar as psychoanalysis can be seen as an active participant in patriarchal social values, we need to show how its terms do not adequately accommodate women's particularities, and differences from men.

The categories that Freud proposed as universally relevant-the function of the phallus, the Oedipus complex, the ubiquity of the castration threat, and women's status as passive-surely need to be contested in order that social relations themselves can be transformed. The choices available to feminist theorists are either to accept psychoanalysis more-or-less wholesale (which implies bracketing off political questions raised by patriarchal power relations); reject it in its entirety (in which case one is left without an account of psychical and fantasy life); or else a little of both (the fetishist's solution), specifically selecting a notion that is deemed impossible or foreclosed by the theory to show how it may not be as implausible as it seems, if the terms themselves are stretched beyond their normal confines. In short, developing paradoxes and contradictions to see how the theory itself copes (or does not cope) with its own unspoken assumptions or unacknowledged implications. 
Јас претпочитам да го имам и едното и другото: психоанализата навистина ги опишува патријархалните односи на моќ и нивното усвојување и интернализирање од страна на обата пола; притоа таа е исто така ограничена од нејзината историска и социо-географрска специфичност. Таа не ги опишува адекватно културите што не се засновани на нуклеарното семејство, ниту пак ги опишува потенцијалните трансмутации и револуционерните пресврти што феминизмот настојува да ги предизвика. Пред сѐ, таа не ја опишува адекватно женската сексуалност дури и во рамките на Западниот капитализам, и затоа таа не е способна да се справи со нејзиниот најнепосреден израз во лезбејските сексуални односи. Ова не значи дека жените/ лезбејките мора исцело да ги напуштат психоаналитичките модели и концепти. Тие сеуште обезбедуваат некои од најполезните изрази за разјаснување на нашите психосоцијални заемни односи. Но, култивираната амбивалентност може да ја обезбеди неопходната дистанца за да се излачи она што може да е од полза во психоанализата при употребувањето на психоаналитичките концепти, како што е фетишизмот, за да се проблематизираат психоаналитичките претпоставки, и да се зачекори отаде нив.

превод Жарко Трајаноски

\section{БЕЛЕШКИ}

I Фетишизмот ја споделува оваа карактеристика со егзибиционизмот, додека клептоманијата се разгледува како еквивалент на феминината перверзија.

2 Ова е аналогно со тврдењето дека порнографијата, исто како фетишизмот, е машки домен; самите тие остануваат неадекватни како форми на сексуално задоволување зашто тие ја сведуваат жената до позиција на (воајеристички/фетишистички) објекти, не субјекти.

${ }^{3} \mathrm{Ha}$ моменти, Фројд сосема драматично го менува своето мислење за негативните и позитивните улоги на перверзиите и неурозите во неговиот напис "Детето е тепано" (1919) каде што тврди дека дури и перверзиите се резултат на потиснување.
I prefer to have it both ways: psychoanalysis does indeed describe patriarchal power relations and their adoption and internalization by both sexes; yet it is also limited in its historical and socio-geographical specificity. It does not adequately describe cultures not based on the nuclear family, nor does it describe the potential transmutations and revolutionary upheavals feminism seeks to effect. Above all, it does not adequately account for female sexuality even within the confines of Western capitalism, and is thus unable to deal with its most direct expression in lesbian sexual relations. This does not mean women/lesbians must abandon psychoanalytic models and concepts altogether. They still provide among the more useful terms in clarifying our psycho-social interrelations. But a cultivated ambivalence may provide the distance necessary to extract what may be of use in psychoanalysis while using psychoanalytic concepts, such as fetishism, to problematize psychoanalytic assumptions and to move beyond them.

\section{NOTES}

' Fetishism shares this characteristic with exhibitionism, where kleptomania is considered the equivalent feminine perversion.

${ }^{2}$ This is analogous to the claim that pornography, like fetishism, is a male preserve; in themselves, they remain inadequate as forms of sexual satisfaction for they reduce women to the position of (voyeuristic/fetishistic) objects, not subjects.

${ }^{3}$ Incidentally, Freud quite dramatically changed his mind about the negative and positive roles of the perversions and neuroses in his paper "A Child Is Being Beaten" (1919a), where he claims that even perversions are the result of repression. 
4 Интересно, Лакан тврди дека фетишизмот е единствената перверзија за која не постои соодвестувачка неуроза (Lacan and Granoff, 265).

${ }^{5}$ Овој пасус вреди да се репродуцира во целост: „Зборот е дар на јазикот а јазикот не е нематеријален. Тој е суптилна граѓa но сепак е граѓa. Тој може да ја оплоди хистеричната жена, тој може да го претставува млазот урина или задржаниот екскремент. Исто така, зборовите можат да претрпат симболички рани. Cе сеќаваме на "Wespe" со кастрирано W, кога човекот волк ја увиде симболичката казна која што му беше наметната од Груша... Имагинарното може да се дешифрира само ако е изразено во симболи" (Lacan and Granoff, 286-289). Накусо, фетишот може да се толкува, не затоа што има каква и да е аналогија или кореспонденција помеѓу пенисот или вагината и фетишот, исто како што соништата не можат да се интерпретираат врз основа на визуелни сличности. Психоанализата е зборувачки лек и како таква се крепи врз вербалното разработување на симптомот и неговиот лингвистички контекст, обезбеден од мрежата на слободни асоцијации. Фетишизмот се јавува во моментот кога имагинарното се уфрла во симболичкото, кога пред-Ојдиповското се трансформира во Ојдиповско, или кога тегобноста се трансформира во вина.

\section{БИБЛИОГРАФИЈА}

Freud, Sigmund. 1895. "Project for a Scientific Psychology." Standard Edition of the Complete Psychological Works of Sigmund Freud (hereafter S.E.). Oxford: The Hogarth Press, Vol. 1, 295-343.

- 1905a. "The Three Essays on the Theory of Sexuality." S.E. Vol. $7,135-243$

- 1905b. "Fragment of an Analysis of a Case of Hysteria." S.E. Vol. 7, 1-122.

Vol. 9,1-93.

-1907. "Delusions and Dreams in Jensen's Gradiva." S.E.

_. 1909. "Notes Upon a Case of Obsessional Neurosis."

S.E. Vol. 10, 151-320.

S.E. Vol. 10.5-149

. 1910a. "Analysis of a Phobia in a Five Year Old Boy."

_. 1910b. "Leonardo da Vinci and a Memory of his Childhood." S.E. Vol 11, 59-137.
${ }^{4}$ Interestingly, Lacan claims that fetishism is the only perversion for which there is no corresponding neurosis (Lacan and Granoff, 265).

${ }^{5}$ This quote is worth reproducing in full: "The word is a gift of language and language is not immaterial. It is subtle matter but matter nonetheless. It can fecundate the hysterical woman, it can stand for the flow of urine or for excrement withheld. Words can also suffer symbolic wounds. We recall the 'Wespe' with a castrated $W$, when the wolf man realized the symbolic punishment which was inflicted upon him by Grouscha.... The imaginary is decipherable only if it is rendered into symbols" (Lacan and Granoff, 286-89). In short, the fetish is interpretable, not because of any analogy or correspondence between the penis or vagina and the fetish, just as dreams are not interpretable based on visual resemblances. Psychoanalysis is the talking cure and as such it relies on the verbal elaboration of the symptom and its linguistic context, provided by the web of free associations. Fetishism emerges at the moment when the imaginary tilts into the symbolic, the pre-Oedipal is transformed into the Oedipal, or anxiety is transformed into guilt.

\section{REFERENCE}

Freud, Sigmund. 1895. "Project for a Scientific Psychology." Standard Edition of the Complete Psychological Works of Sigmund Freud (hereafter S.E.). Oxford: The Hogarth Press, Vol. 1, 295-343.

—. 1905a. "The Three Essays on the Theory of Sexuality." S.E. Vol. 7, 135-243

-. 1905b. "Fragment of an Analysis of a Case of Hysteria." S.E. Vol. 7, 1-122

—. 1907. "Delusions and Dreams in Jensen's Gradiva." S.E. Vol. 9,1-93.

-. 1909. "Notes Upon a Case of Obsessional Neurosis." S.E. Vol. 10, 151-320.

S.E. Vol. $10.5-149$

—. 1910a. "Analysis of a Phobia in a Five Year Old Boy."

—. 1910b. "Leonardo da Vinci and a Memory of his Childhood." S.E. Vol 11, 59-137. 
1914. "On Narcissism: An Introduction" S.E Vol. 14, 73-102.

1915. "Repression." S.E. Vol. 14,146-58.

—. 1919a. "A Child is Being Beaten': A Contribution to the Study of the Origin of Sexual Perversions." S.E Vol. 17,179-204.

64.

__ 1919b. "Beyond the Pleasure Principle." S. E Vol. 18, $7-$

in a Woman." S.E Vol. 18,147-72.

1923. "The Ego and The Id "S.E Vol. 19, 13-66.

1924. "Neurosis and Psychosis." S.E Vol. 19,149-53.

cal Distinction

- 1925a. "Some Psychical Consequences of the Anatomi-

Between the Sexes." S.E Vol. 19, 248-58.

—_. 1925b. "Negation." S.E Vol.19, 235-39.

—. 1927. "Fetishism" S.E Vol. 21,152-57.

S.E Vol. 23

- 1940. "Splitting of the Ego in the Process of Defence."

Hopkins, Juliet. 1984. "The Probable Role of Trauma in a Case of Foot and Shoe Fetishism: Aspects of Psychotherapy of a Six Year Old Girl." In International Review of Psychoanalysis 11:79-91.

Lacan, Jacques. 1953. "Some reflections on the Ego." In International Journal of Psychoanalysis 34. don: Tavistock

- 1977a. Ecrits. A Selection. Trans. Alan Sheridan. Lon-

- . 1977b. The Four Fundamental Concepts of Psychoanalysis. Trans. A.M. Sheridan. London: Tavistock.

Lacan, Jacques and W. Granoff. 1956. "Fetishism: The Symbolic, The Imaginary and The Real." In Perversions, Psychodynamics and Therapy. Ed. Michael Balint. London: Tavistock, 165-76.

Lorand, Sandor. 1930. "Fetishism in Statu Nascendi.: In International Journal of Psychoanalysis 11, 4: $419-27$.

Schor, Naomi. 1985. "Female Fetishism: The Case of George Sand." In The Female Body in Western Culture. Ed. Susan Rubin Suleiman. Cambridge: Harvaed University Press.
1914. "On Narcissism: An Introduction" S.E Vol. 14, 73-102.

1915. "Repression." S.E. Vol. 14,146-58.

-. 1919a. '"A Child is Being Beaten': A Contribution to the Study of the Origin of Sexual Perversions." S.E Vol. 17,179-204.

64.

_. 1919b. "Beyond the Pleasure Principle." S. E Vol. 18, 7-

- 1920. "The Psychogenesis of a Case of Homosexuality in a Woman." S.E Vol. 18,147-72.

1923. "The Ego and The Id "S.E Vol. 19, 13-66.

1924. "Neurosis and Psychosis." S.E Vol. 19,149-53.

cal Distinction

. 1925a. "Some Psychical Consequences of the Anatomi-

Between the Sexes." S.E Vol. 19, 248-58.

—. 1925b. "Negation." S.E Vol.19, 235-39.

—. 1927. "Fetishism" S.E Vol. 21,152-57.

S.E Vol. 23

—. 1940. "Splitting of the Ego in the Process of Defence."

Hopkins, Juliet. 1984. "The Probable Role of Trauma in a Case of Foot and Shoe Fetishism: Aspects of Psychotherapy of a Six Year Old Girl." In International Review of Psychoanalysis 11:79-91.

Lacan, Jacques. 1953. "Some reflections on the Ego." In International Journal of Psychoanalysis 34. don: Tavistock.

—. 1977a. Ecrits. A Selection. Trans. Alan Sheridan. Lon-

1977b. The Four Fundamental Concepts of Psychoanalysis. Trans. A.M. Sheridan. London: Tavistock.

Lacan, Jacques and W. Granoff. 1956. "Fetishism: The Symbolic, The Imaginary and The Real." In Perversions, Psychodynamics and Therapy. Ed. Michael Balint. London: Tavistock, 165-76.

Lorand, Sandor. 1930. "Fetishism in Statu Nascendi:: In International Journal of Psychoanalysis 11, 4: $419-27$.

Schor, Naomi. 1985. "Female Fetishism: The Case of George Sand." In The Female Body in Western Culture. Ed. Susan Rubin Suleiman. Cambridge: Harvaed University Press. 